\title{
Eurostudia
}

\section{Between the Cross and the Crescent: Marking One's Territory and Intercultural Coexistence in Orthodox-Muslim Relations in Macedonia}

\section{Goran Sekulovski}

Volume 13, numéro 1-2, 2018-2019

Cultures en contact, entre régulations et représentations

URI : https://id.erudit.org/iderudit/1064491ar

DOI : https://doi.org/10.7202/1064491ar

Aller au sommaire du numéro

Éditeur(s)

Le Centre canadien d'études allemandes et européennes

ISSN

1718-8946 (numérique)

Découvrir la revue

Citer cet article

Sekulovski, G. (2018). Between the Cross and the Crescent: Marking One's Territory and Intercultural Coexistence in Orthodox-Muslim Relations in Macedonia. Eurostudia, 13(1-2), 115-137. https://doi.org/10.7202/1064491ar

\section{Résumé de l'article}

Cet article vise à analyser les rapports complexes islamo-orthodoxes, en prenant comme étude de cas la République de Macédoine. Au cours des dix dernières années dans le pays ont été construits près de 350 nouvelles mosquées et minarets, et presque autant de nouvelles églises, monastères et chapelles. Résultat prospectif, il y a actuellement près de 2000 églises et 600 mosquées, ou bien une église ou mosquée pour tous les 800 habitants. Pour comprendre ces nouvelles logiques de marquage symbolique de l'espace au sein des communautés religieuses, il faut aller au-delà du paysage pour faire ressortir la coexistence interculturelle et pour analyser les politiques publiques en matière religieuse. Tels sont certains des enjeux auxquels tente de répondre cet article en attachant un poids égal à différents champs d'étude : l'analyse de l'espace religieux, l'interculturalisme et la politique publique.
Tous droits réservés ( Le Centre canadien d'études allemandes et européennes, 2019
Ce document est protégé par la loi sur le droit d'auteur. L'utilisation des services d’Érudit (y compris la reproduction) est assujettie à sa politique d'utilisation que vous pouvez consulter en ligne.

https://apropos.erudit.org/fr/usagers/politique-dutilisation/ 


\title{
Between the Cross and the Crescent: Marking One's Territory and Intercultural Coexistence in Orthodox-Muslim Relations in Macedonia
}

\author{
Goran Sekulovski \\ Institut Saint-Serge (Paris) / Géographie-Cités (équipe EHGO)
}

\section{Résumé}

Cet article vise à analyser les rapports complexes islamo-orthodoxes, en prenant comme étude de cas la République de Macédoine. Au cours des dix dernières années dans le pays ont été construits près de 350 nouvelles mosquées et minarets, et presque autant de nouvelles églises, monastères et chapelles. Résultat prospectif, il y a actuellement près de 2000 églises et 600 mosquées, ou bien une église ou mosquée pour tous les 800 habitants. Pour comprendre ces nouvelles logiques de marquage symbolique de l'espace au sein des communautés religieuses, il faut aller au-delà du paysage pour faire ressortir la coexistence interculturelle et pour analyser les politiques publiques en matière religieuse. Tels sont certains des enjeux auxquels tente de répondre cet article en attachant un poids égal à différents champs d'étude: l'analyse de l'espace religieux, l'interculturalisme et la politique publique.

\section{Abstract}

This article analyses the complex relations between Orthodox Christians and Muslims in the Republic of Macedonia. Over the last ten years, 350 new mosques and minarets have been built in the country, and nearly as many new churches, monasteries and chapels. As a result, there are presently nearly 2000 churches and 600 mosques in the country, which is equivalent to one church or mosque for every 800 inhabitants. In order to understand the operative logic of these 
developments, whereby religious communities symbolically mark their territories, we must go beyond the question of landscape and highlight the dynamics of intercultural coexistence through an analysis of public policies on religious matters. These are some of the questions which this article attempts to deal with, attaching equal importance to various areas of study: religious landscape, interculturalism and public policies.

\section{Introduction}

If $^{1}$ religions are defined by doctrines, norms and principles, they find material grounding in a geographic space which is not accidental. The way a religion appropriates geographical space is a good indicator of that religion's content. What this article intends to deal with is not so much a general presentation of the different ways in which geographical space is absorbed into a religion's outlook, but rather the ways in which religion manifests itself in a particular space, in this case, the Republic of Macedonia. I deal with this concrete example by closely analysing the relations between Orthodox Christians and Muslims in that country, on the one hand through the concept of "marking one's territory", described by Veschambre (2004) and, on the other hand, that of inter-culturalism (Meer, Modood and Zapata-Barrero 2016).

This initial approach enables us to explain the interaction between markings and appropriations because "symbolically marking a space is intended to signal appropriation. By positioning objects or otherwise intervening on the inhabited space, it constitutes the most significant material aspect of appropriation" (Brunet,

\footnotetext{
${ }^{1}$ The author would like to thank Stéphane Bigham from the University of Sherbrooke for providing language help.
} 
Ferras and Théry 1993: 193). The link between markers and appropriation is indisputable, as all forms of appropriation, from the most symbolic to the most physical, are accompanied by acts which mark the space. At the same time, the concept of marking one's territory highlights the connection between spatial markers, power, and symbolic violence. Indeed,

markers function as symbolic violence when they represent a lasting affirmation of forms of appropriation of space whose socially arbitrary nature is ultimately no longer perceived, thus avoiding the ongoing use of force [needed] to impose power in a given space (Veschambre 2004: 74).

From this perspective, we understand presence-marking as a form of territorial violence that uses the symbolic nature of places to impose an identity on both the collective consciousness and spatial practices, ultimately producing territories which are based on identity.

Constructions and reconstructions of religious buildings are at the heart of memorial conflicts insofar as these processes constitute a symbolic marking of space. Such spatial markers can become encompassing or exclusionary as soon as they take place at the boundary between religious communities. The goal of this paper is to analyze how the Orthodox Christian and the Muslim communities manifest themselves in space and then to clarify the distinction between the material and symbolic aspects of their (re)construction of religious buildings. These spatial markers operate on two levels: they create meaning by means of symbolism and ideals. But at the same time, and however symbolic, these markers are always grounded in physical actions such as the creation or repurposing of significant and enduring landmarks (e.g. houses of worship or monuments) that leave lasting traces. They may also take the form of the actual symbols attached to such landmarks (crosses and crescents), which simultaneously "mark" their observers and associate the place with a given social group. 
With regard to intercultural coexistence, it seems necessary not to get bogged down in the exaggerated use of the word multiculturalism, especially in Europe where this new buzzword can designate a rather static vision of cultures, for instance, in the phrase: "multiculturalism without culturalism" (Vermeulen and Slijper 2002: 30-31). It conveys an understanding mainly based on ethnic belonging and the homogenization of different groups according to a singular principle: excluding cultural differences. This trend is encouraged by the gradual emergence of a supranational European federation. As Heller (1996: 25-26) emphasized, multiculturalism can neutralize, from the inside, its own prerogatives, and can, under the pretense of a plurality of cultures, "fall into the ideology of monoculturalism." There, the concept of multiculturalism is condemned to remain vague, becoming just a banal, politically correct slogan.

\section{Methods and sources}

During the course of my research, I have mainly used two kinds of data: bibliographic and documentary sources in the broadest sense (books, reports, surveys) on the nature of representations of identity among Orthodox Christians and Muslims, and empirical work or field research. Various aspects of the Orthodox Christian presence in Macedonia are analyzed in my recent book (Sekulovski 2019). With regard to Islam, research in French on the Balkans has only recently begun to emerge. The question of Islam and its "astonishing rebirth" in the Balkans have mainly been covered by historians, such as Popović (2009) for the post-Ottoman period and Clayer (2001; Clayer and Bougarel 2013) for the interwar and post-communist periods, focusing on the close links between Albanian nationalism and religious identity. However, these studies of Islam in Macedonia have left Muslim-Orthodox relations largely unexplored. More broadly, these interactions have yet to benefit from critical attention, a gap which this article attempts to fill. 
The field research used in this article was completed in April and May 2016. Field research offers several advantages. It forces the researcher to constantly strive for taking into account the concrete situation, particularly in a situation where both the subject itself and the questions of identity involved are extremely sensitive. Interviews with approximately twenty individuals (citizens, religious leaders) were very helpful in providing a kind of nuanced understanding of religious and identitary questions about which the written record lacks adequate detail.

\section{Macedonia between Orthodoxy and Islam}

Disregarding certain spatial and temporal particularities of an especially local nature, the historical development of the Republic of Macedonia resembles that of its neighbouring states. All of whom have in different ways lived through the Ottoman domination, a nationalist awakening, a socialist regime, the Yugoslav wars, the process of democratization, and the birth pangs of the market economy required by EU membership of the entities created by the breakup of Yugoslavia.

The Republic of Macedonia has a little more than two million inhabitants, of which 1.3 million are Orthodox Christian and nearly 700000 are Muslim (State Statistical Office 2002, 334). According to the latest indicators of religious affiliation and atheism (2012) - a poll carried out by WIN-Gallup International ${ }^{2}$ - Macedonia is the second most religious country in Europe after Armenia (ahead of Romania, Georgia, Moldavia and Poland) and ranks as the fifth most religious country in the world by percentage of the population: $90 \%$ is religious, while only $1 \%$ is atheist, and $8 \%$ are non-religious. According to another poll carried out in 2010 by Gallup

\footnotetext{
2 The religious indicator represents the percentage of the population that considers itself "religious." The results of the poll, in which 51,927 people took part between November 2011 and January 2012 in 57 countries, can be seen at this website: https://web.archive.org/web/20121016062403/http://redcresearch.ie/wp-content/uploads/2012/08/RED-Cpress-release-Religion-and-Atheism-25-7-12.pdf. Last visited on 11 December 2018.
} 
Balkan Monitor and the European Fund for the Balkans ${ }^{3}$ which measured the satisfaction with, and confidence in, state institutions, Macedonian citizens have the greatest confidence in religious organizations, even before the national army.

This exceptional place given to religious affiliation cannot be neglected in the analysis of Macedonian cultural identities. As the polls indicate, religious affiliation and ethnic identity are closely intertwined. In other words, the confidence of the population in ecclesiastical institutions and confessional communities cannot be separated from ethnic affiliation. Thus, $70 \%$ of ethnic Macedonians, essentially associated with Orthodox Christianity, have great confidence in the Macedonian Orthodox Church (Makedonska Pravoslavna Crkva) ${ }^{4}$, whereas $20 \%$ of ethnic Macedonians have no confidence in the Islamic Religious Community (Islamska Verska Zednica). The results are quite similar among the Albanian population in Macedonia, where $77 \%$ express a near unshakable confidence in Islamic institutions ${ }^{5}$, and only $11 \%$ of Albanians have confidence in the Macedonian Orthodox Church (Klekovski et al. 2008: 19).

At the same time, these numbers do not take into account the diversity of denominations within the two great religious communities, nor individual adherence to other, more marginal, religions. Thus, besides Orthodox Christians and Muslims, there are more than 60000 citizens in Macedonia belonging to other religious groups, including Catholics, Protestants, or Jehovah's Witnesses. Among these, the order of Muslim Bektachis Dervishes is in direct conflict with the Islamic Community. Similarly, the members of the Orthodox Archdiocese of Ohrid are in

\footnotetext{
3 The detailed results of this poll are available at https://www.esiweb.org/enlargement/wpcontent/uploads/2009/02/2010 Summary of Findings.pdf, last visited on December 11, 2018.

${ }^{4}$ Established in 1967, without recognition of its canonical status (independence) by the other Orthodox churches.

${ }^{5}$ Established in 1994, after the dissolution of Yugoslavia.
} 
conflict with the Macedonian Orthodox Church which is greatly protected by the State.

As regards the relations between the State and the various religions (Ilievski 1996), Macedonia represents a half-secular model between a State Church and a total separation between Church and State. It lies somewhere in between the French separation of Church and State, on the one hand, and any of the several Eastern theocracies, on the other. Indeed, Macedonia follows the German model where, although Church and State are in theory separate, the State nevertheless supports the Church in a number of indirect, discreet ways. Unlike France, the Macedonian model is primarily characterized by the positive integration of churches into public space.

\section{The State and the Management of Religious Plurality and Education}

The Macedonian Constitution guarantees freedom of religion and recognizes the right to freely and publicly express one's faith, individually or collectively (art. 19). The legal status of religious communities as well as the relations between the state and religious communities and groups are regulated by the State Commission for the Relations between Religious Communities and Groups (Komisija za odnosi so verskite zaednici i religiozni grupi).

The Macedonian parliament also has a Committee for Intercommunity Relations made up of 19 deputies. Seven of its members come from the Macedonian side (Orthodox) and seven from the Albanian side (Muslim), with one member for each of the other communities: Turkish (Muslim), Wallachian (Orthodox), Rom (Muslim), Serbian (Orthodox) and Bosnian (Muslim). The parliament elects the members of the Committee who then examine and evaluate the problems relating to intercommunity relations in Macedonia and make recommendations for solutions. The parliament is required to take into 
consideration the evaluations and proposals of the Committee and to make decisions in agreement with its directives. Similar committees also exist at the municipal level.

For its part, the Culture Ministry has organized three world conferences on interreligious and inter-civilizational dialogue, held in Ohrid in 2007, 2010, and 2013. The first two meetings reflected a harmonic, Orthodox-Muslim coexistence, but the Macedonian Islamic Community did not participate in the third conference due to its conflict with state authorities over the reconstruction of the ancient Burmali mosque in the center of Skopje ${ }^{6}$. The designated plot of ground for the mosque was instead used for the building of an Officers' House (Oficerski dom).

\section{Mutual Ignorance and the Symbolic Fight for Places of Worship}

The two main communities studied in this article, Orthodox and Muslim, define themselves in relation to each other by their belonging to an ethnic group or to their faith in a religion, that is, belonging to societies marked by these two elements. The members of each group are poorly acquainted with the religion of the other (Tegovska and Petkukeska 2011). Therefore, we have on this matter two parallel situations: in general, Orthodox believers know little about Islam, and Muslims know little about Orthodoxy. In fact, this is one of the conclusions of the ninth (and latest) Official Consultation between Orthodox and Muslims held in Amman, Jordan, in 1998 on the theme of the image of the other:

\footnotetext{
${ }^{6}$ The Ottoman Mosque of Burmali was built in 1495 by Mehmed Bey, being one of the rare Mosques built on the right bank of Vardar which forms the new district of the capital and which began to be densely populated mainly by Christians in the $19^{\text {th }}$ century. Even today, more than $95 \%$ of the population in this part of the city is Christian. On the left bank of Vardar is the old city of Skopje where more than $95 \%$ of the urban Muslim population lives. The Burmali Mosque was destroyed in 1925 by Serbian authorities and the Officers' House was built in its place. The House existed until 1963 when it was destroyed by a devastating earthquake that struck Skopje. Since then the site has remained empty even though it is located in the downtown area on the main square of the Macedonian capital.
} 
One of the main problems which Muslims and Christians have to confront is the image the ones have of the others, and each group's knowledge of the other's religion is more or less confused. Real knowledge of the other and his religion is limited, on both sides, to a small minority (Papandreou 1998: 20).

This reciprocal ignorance allows political parties on both sides to manipulate religious feelings and to identify the presence of the other as an aggression, especially in the run-up to elections.

On a broader level, this phenomenon of mutual ignorance has made it difficult to understand the massive expansion of the number of places of worship and sacred places in Macedonia during the last 15 years (2002-2017). Behind these recent developments are different actors that will be discussed throughout the article: the state, which promotes and funds these building projects mainly on the Orthodox side; such local funders as churches, Islamic institutions, municipalities and businessmen; or even foreign funders like Saudi Arabia in the case of the new Muslim mosques.

The construction of the so-called Millennium Cross on the top of the Vodno Commune south of Skopje as well as that of the Plaošnik Church, St. Clement of Ohrid, in Ohrid in 2002, inaugurated a rush of rather visible support for the Church by the Macedonian state, by way of payments made from public taxes for the construction of religious buildings on state-owned land. Immediately after the 2006 elections, the government also decided to finance the construction of the St. Constantine and St. Helen Church on the central plaza of the capital, just beside the statue of the "Warrior on Horseback." It was built on a lot ceded by the Macedonian government under rather dubious legal circumstances and the Culture Ministry even named the project supervisor. Moreover, there was no provision for such a building in the urban development plans. This affair provoked the indignation of the Islamic Community which immediately demanded the 
building, or rather the rebuilding, of the historic Burmali Mosque in the center of Skopje.

Churches and mosques have coexisted in that area for centuries. Notably, the $12^{\text {th }}$ century steeple of St. Panteleimon still stands on the slopes of Vodno Hill right next to the $15^{\text {th }}$ century minaret of Mustafa Pacha. Despite all this, the recent erecting of such religious symbols as the Millennium Cross, which overlooks a multi-confessional city, has been seen as a "blessing"7 by one side and as an "aggression" 8 by the other. The two religious organizations have accused each other of being aggressive and of lacking respect for the law in their mutual construction of religious buildings ${ }^{9}$. What is more, the Macedonian Church accused the Islamic Community of having conquered zones where Orthodox Christians traditionally lived, and therefore the Church felt compelled to erect this massive cross and build chapels and churches to defend its ethnic-religious space from the "encroachment" of Muslims ${ }^{10}$.

This reaction of the Orthodox population to the Muslims' marking of space is, in part, due to the process of "Albanization" of Islamic religious buildings, which started in the early 1960s and which was inherited from the Ottoman period (Gjorgiev 2011). In fact, the majority of the Ottoman population which constituted the largest number of Muslims during the Balkan Wars (1912-1913) and then the First World War (1914-1918) emigrated to Turkey in the 1950s and early 1960s. After their departure, the Albanian community inherited the title of most populous group of Muslims in Macedonia. The Ottoman religious buildings, in which Turkish was the language of sermons until 1963, passed into Albanian hands, and

\footnotetext{
${ }^{7}$ Interview with J. Markov, citizen, Skopje, May 2016.

${ }^{8}$ Interview with X. Jashari, citizen, Skopje, April 2016.

${ }^{9}$ To understand the political activity of religious organizations in the post-socialist countries of Central and Southeastern Europe see Ramet (2014).

${ }^{10}$ Interview with T. Stefanovski, lay employee of the Macedonian Orthodox Church, Skopje, April 2016.
} 
since then Albanian has become the dominant language in the religious services of the Islamic community.

The "Albanization" of these Islamic religious buildings has thus provoked a change among the Orthodox citizens in Macedonia in their perception of Islam and of the Ottoman heritage. The old equation between Muslim and Turkish that had existed before, now changed to that of Muslim equals Albanian. As such, the old buildings were no longer seen by the Macedonians as the cultural and monumental heritage of the Ottomans, but now as religious buildings where radical Albanians met, among other kinds of Muslim believers. This identification of every Islamic religious building with Albanian nationalism prevented Macedonians from accepting the presence of an Islamic buildings in the space where Macedonians were the majority, even if the building itself has stood through 400 years of Ottoman occupation. From a Macedonian perspective, these buildings had acquired an "Albanian nationality"11 of sorts and had become centers of Albanian nationalism (Clayer 2001). For these reasons, at the time of the MacedonianAlbanian conflict in 2001, one of the main targets of the warring parties was religious buildings.

This conflict about places of worship, which is equally true for the Muslim community's attitude toward Orthodox buildings, perpetuates the ethnocentric perceptions about matters of faith and greatly contributes to the division of Macedonian society along religious lines, thus threatening the very existence of the state. Since its independence in 1991, the Macedonian state has not shown the necessary ability to absorb and transcend the nationalisms that go hand in hand with belonging to religious communities.

\footnotetext{
${ }^{11}$ Interview with A. Spasovska, citizen, Skopje, April 2016.
} 


\section{Religious Need or Marking One's Territory?}

According to the latest inquiries in 2011, there are 1952 churches and 580 mosques in Macedonia (Pavlovska, Nikiforovik and Kocevski 2011) plus at least 50 churches and 15 dozens of mosques in the building or rebuilding process. This means that there is one church or mosque for every 800 inhabitants. It is important to understand that the map I provide of the religious landscape of the Republic of Macedonia (see fig. 1) does not represent a reality (i.e. the 'territories' of each religion) but, as Gardiner and Engler suggest, "a guide to research" and "experiment to science's continuing development" (2010: 11). Two important distinctions must be drawn in our use of maps to represent spaces of conflict: one between the different levels of representation; and the other between the representing and guiding function of maps (Gardiner and Engler 2010: 1).

Despite this symbolic marking of one's territory, both the Orthodox Church and the Islamic Community demand the construction of new religious buildings because, according to them, the present-day structures are too small for all the believers. Notwithstanding such claims, the results of a survey carried out in 2011 by Tegovska and Petkukeska showed that the opposite is true. Indeed, the survey showed that $74.2 \%$ of Orthodox residents thought that the country had enough churches, and as many as $20.4 \%$ of them thought that there were already too many. Likewise among the Muslim population, only $44.6 \%$ thought that there were enough mosques, but the same proportion (43.1\%) felt that there was already more than what was needed.

When asked whether there were currently enough religious buildings in Macedonia, $44.6 \%$ of respondents felt that religious construction projects were mainly intended to "mark territorial influence," according to another study on religious influence on Macedonian society and politics (Božinovski and Nikolovski 2019). Still, the leaders of the Islamic Community, for example, have remained 
adamant that the 580 mosques in Macedonia do not meet the needs of their faithful. According to its secretary general ${ }^{12}$ :

our believers are constrained to pray in the courtyards or outside during the Friday prayers because there is not enough space inside. In Prilep, more than 10000 of our faithful have no place to pray because the state does not permit the reconstruction of the burned "Charshi" mosque. It is a false impression that many mosques are being constructed while in fact the needs of the faithful are being neglected.

In the capital Skopje and in the suburbs, a great deal of energy is being spent constructing new churches, chapels, crosses, minarets, and mosques and other religious symbols. The example of Skopje is being followed by municipalities across the country which have launched their own initiatives for constructing religious buildings, offering lower taxes and city-tax exemptions for construction companies. Thus, eminent businessmen, public figures, and politicians have joined the race to build churches in visible places so as to mark their territory.

A striking example of the marking of one's territory with religious symbols can be found in the construction of a Church museum as well as a church within the walls of the Kale, the old Ottoman fortress, at the beginning of 2010. Then, riots and confrontations took place between Orthodox (Macedonians) and Muslims (Albanians). This is why the Kale, even today, is closed to visitors. This example of Kale in Skopje confirms once again the ethnic and religious polarization of the whole country. The separation of the population in two parts affects in no small way the identities of the two cultures, and encourages an ever-present climate of potential crisis. The topography of urban settlement in Skopje represents this state of things better than all political theories and ideas.

\footnotetext{
${ }^{12}$ Interview with A. Tairi, secretary general of the Islamic Religious Community, Skopje, May 2016.
} 
On the Muslim side as well, over the last ten years in Macedonia, some 350 new mosques and minarets have been constructed, and nearly 90 of them on the Skopje-Tetovo-Gostivar line and in the villages at the foot of the Šar mountains (cf. fig. 1), where there is a significant portion of the Albanian population. A certain number of these mosques are found in totally uninhabited areas, such as at Suva Gora and on the western slopes of Vodno. In the village of Tearce, for example, which does not have a significant Muslim population, an old mosque was restored and the construction of a new one had been started, alongside with a new church ${ }^{13}$.

While the number of mosques has more than doubled over the past decade, the increase in the number of churches has been slower. However, Macedonia's Orthodox population is nearly twice the size of its Muslim population. Based on the number of places of worship, the presence of Orthodox churches related to the number of believers is still higher than that of mosques. This leads us to the following questions: is the growth of mosques to be understood as a mean to counterbalance the marginalized presence of Muslims in the Macedonian religious landscape? And must the increase of Orthodox churches to be perceived as a desire to maintain the Orthodox prevalence over Islam?

The reasons for building new places of worship have little to do with the religious and spiritual needs of the local population. They are mostly symbolic acts of marking one's own territory. The country's high degree of religious affiliation is not matched by the actual religious practice of its population. Indeed, 31.5\% of Macedonia's Orthodox population only attends church on major religious feasts, which are also legal holidays, which is to say once or twice a month (Cacanoska

\footnotetext{
${ }^{13}$ For other examples, two new, unfinished mosques were constructed in Trebište and in Rostuše (near Debar) after 2006. At the edge of Tetovo, there is an unfinished mosque while ten new mosques have been built on the Gostivar-Bogovinje line. New mosques have also been built in the villages of Chegrane, Forino (the Gostivar region), Slupchane, Vaksince and Lipkovo (the Kumanovo region). Seven mosques have been restored or rebuilt in Kičevo during the last eight years, and recently a headstone was laid for another mosque, the eighth. New ones have also appeared in Valandovo and Demir Hisar.
} 
2016: 18). In response to the question, "on average, how often do you attend church," just $9.8 \%$ of respondents said they attended liturgy, went to confession and received Communion every Sunday (Božinovski and Nikolovski 2016). According to that same survey of "Citizens' Perception of Religion and its Role in Multi-confessional Societies," 41.9\% of Orthodox Macedonians' religious practice remains associated with significant life events, such as baptisms, weddings, and funerals, and major religious feasts like Christmas and Easter. For example, in the big Orthodox church in Skopje, St. Clement of Ohrid Cathedral, there are at present no more than 50 faithful attending Christian feasts.

Religious attendance among Muslims presents a very different picture: $19.2 \%$ of respondents go to the mosque every day, $18.3 \%$ every week, $10 \%$ once a month and $13.3 \%$ several times a year for major religious holidays (Božinovski and Nikolovski 2016: 8). These results clearly show that Muslims practice their religion more than Orthodox Christians ${ }^{14}$. The mosques in Skopje are filled mostly during the Friday prayer service, Jumu'a. However, around Skopje, in many villages like Paligrad, Aldinci or Crvena Voda, there are no longer any faithful or even an imam. In deserted villages, only the minarets are visible as guardians of a territory reserved for the Islamic Community.

Whatever the denomination of the new holy places of worship, they do not necessarily endanger the existing landscape, the panoramas, or the spatial landmarks or objects that are already symbols of a city or villages for the inhabitants. The contemporary evolution of societies sets before us much more complex questions. Why is such evolution marked by communities that are turning in on themselves, thus impeding intercommunal life in areas like Macedonia? After all, Macedonia has for a long time represented a meeting place

\footnotetext{
${ }^{14}$ The figures, reported by Jahja (2014: 398), whereby 200000 Muslims practise on a daily basis and 300000 on Fridays and fasting for Ramadan, need to be backed up by relevant and credible data.
} 
for many diasporas. Is dialog enabling a better coexistence between Orthodox and Muslims possible?

\section{Going beyond the Landscape: What Kind of Dialogue for Macedonia?}

Today, Orthodox and Muslims in the Republic of Macedonia, as individuals or as groups, are intimately involved in the mixing of cultures and globalization. The fear of losing familiar landmarks has, however, encouraged them to seek "new points of orientation," to "strengthen old boundaries and to create new ones, often based on identities of resistance," thus increasing the gulf between "us" and the “other" (Paasi 2003: 475).

A wider vision of religious identity and the inevitability of conflict is thus necessary. The shock of colliding religions does not slow down the implosion of cultures. When we consider the relations between Macedonian Orthodox and Muslims, we need to emphasize that we are not dealing with two civilizations. At most, by using the Germanic and Slavic distinction between civilization and culture, we can speak of two cultures within a same civilization. Still, it must be

observed that, between the two cultures, dialogue is possible but only with some degree of a "stubborn respect" (Talbi and Clement 1989). There are common notions and values, yet they are often forgotten in the present-day climate of confrontation.

So then, how is it possible to enter into a dialogue in a different way? After the fall of the Ottoman Empire, the dialogue between the two religions had been put on hold. Yet, contacts have only recently been re-started: the official interreligious dialogue between Orthodox and Muslims began for the first time in 1984, through the collaboration between the Royal Jordanian Academy of Islamic Civilization and the Independent Commission of Islamo-Christian Relations in England (Sharp 2012). That dialogue extended over nine meetings, between 1986 
and 1998, at the Orthodox Center in Chambésy-Genève and at the Royal Jordanian Academy of Islamic Civilization ${ }^{15}$. The main goal of the dialogue between Orthodox and Muslims has been to improve the way each group perceives the other. It has aimed notably at removing the negative image of the past, and at abandoning hostile prejudices that have taken root over the centuries.

There seems to be two ways of analyzing this dialogue, both of which are contradictory. On the one hand, we notice a sort of voluntary optimism. With great ease, this mode of thinking vaunts cohabitation, coexistence, the accepting of differences, even the mixing of cultures in a situation where mutual confidence is supposed to deepen and where negative stereotypes of the other fade away. From this point of view, cities are seen as "the first arena for the fight for rights, independence, and identity" (Sassen 1996: 197). Even the very word 'border' between Orthodox and Muslims is supposed to refer to a zone where things come together rather than a line of demarcation. Indeed, borders do not only separate groups and communities, they might also serve as points of meeting, establishing contact and cultural encounter.

On the other hand, the historical analysis tends to be pessimistic, prudent. It underlines the opposite: the misfortune of this communitarian approach. When differences become polarized, is not violence then used to endorse the legitimacy and the permanent aspect of religious identity? The insistence on otherness, the accentuation of individuality, the marking of boundaries and the categorizing of others, are these not at the same time the expression and consequence of their strength? Thus Debray aptly promises: "give me a border and a threat and I will make you a community: the grammar of civilizations has something inalterable. And if, according to the adage, the 'me' poses itself in opposition, the 'we' also"

\footnotetext{
${ }^{15}$ The minutes of all nine meetings between the Orthodox and Muslim delegates have been published in the journal Episkepsis of the Orthodox Center of the Ecumenical Patriarchate in Chambésy-Geneva.
} 
(2005: 158). Moreover, this is what explains how in the Republic of Macedonia, Orthodox and Muslims are, above everything else, caught in a centuries-old, ethnic dilemma, and as such are unable to get out of their respective ethnic trenches: Macedonians/Albanians (Sekulovski 2014).

So cultural identities are henceforth lived as an essential, personal, and reflexive characteristic, the modern individual takes refuge in what is part of his immediate identity: family, neighbourhood, ethnic group, religion, seeing the larger society as a mythical reality which he cannot control. Instead of multiculturalism, the term inter-culturalism (Meer, Modood and Zapata-Barrero 2016) is certainly better suited to describe Macedonia because it puts a greater emphasis on the relations between the two different cultures and religions. The experience of subjective, intercultural coexistence-that is, of people living together-which continues in Macedonia and exists alongside the objectivity of existing political and economic conditions, is no doubt one of the key elements that allow the Macedonian state to survive. In the tense climate, where great political speeches about the national identity and the dangers that surround it clash like thunderbolts, the majority of Orthodox and Muslims face the reality that there is only one protector of their coexistence: the state.

\section{Conclusion}

In the southern Balkans, through six centuries of history, Orthodox and Muslims, among other religious groups, have lived together and continue to do so today in the Republic of Macedonia. If this mixed group of people, living in a small territory (with a radius of 100 kilometers) and held together by the grip of mutual interest, were able to adopt a common constitution, beneficial to everyone and meeting everyone's needs in an equitable manner, then the state, by having a solid "backbone," could begin to function as an organized whole, and citizens could come together as one nation that would finally define an uncontested identity. 
It would be, moreover, a serious illusion to believe that the two religious communities will suddenly change their civic attitudes toward the state: religious identity is and will most probably continue to be defined in ethnic terms. All the same, the conflict is not limited, or not just limited, to one between Orthodox and Muslims.

The link between nation, Church and Mosque in the Balkan context will no doubt remain the main obstacle to a peaceful intercultural coexistence. Instead of going beyond culture, which religion and politics applaud, and of transcending the nation they protect, the Church and the Mosque tend to be considered, and even to consider themselves, as components of the national culture, displaying within themselves, moreover, a certain national messianism (in the present case, Macedonian or Albanian).

And finally, it is necessary in today's society to show that the history of Orthodoxy and Islam in Macedonia cannot be neglected. If it is true, that there will be a time of renewal in the future, Orthodox and Muslims will have to reopen their histories as well as the possibility of another way of reading it. Consequently, one should not underestimate the usefulness of scholarship in monitoring the differences of interests which are perfectly normal in the interreligious relations. 


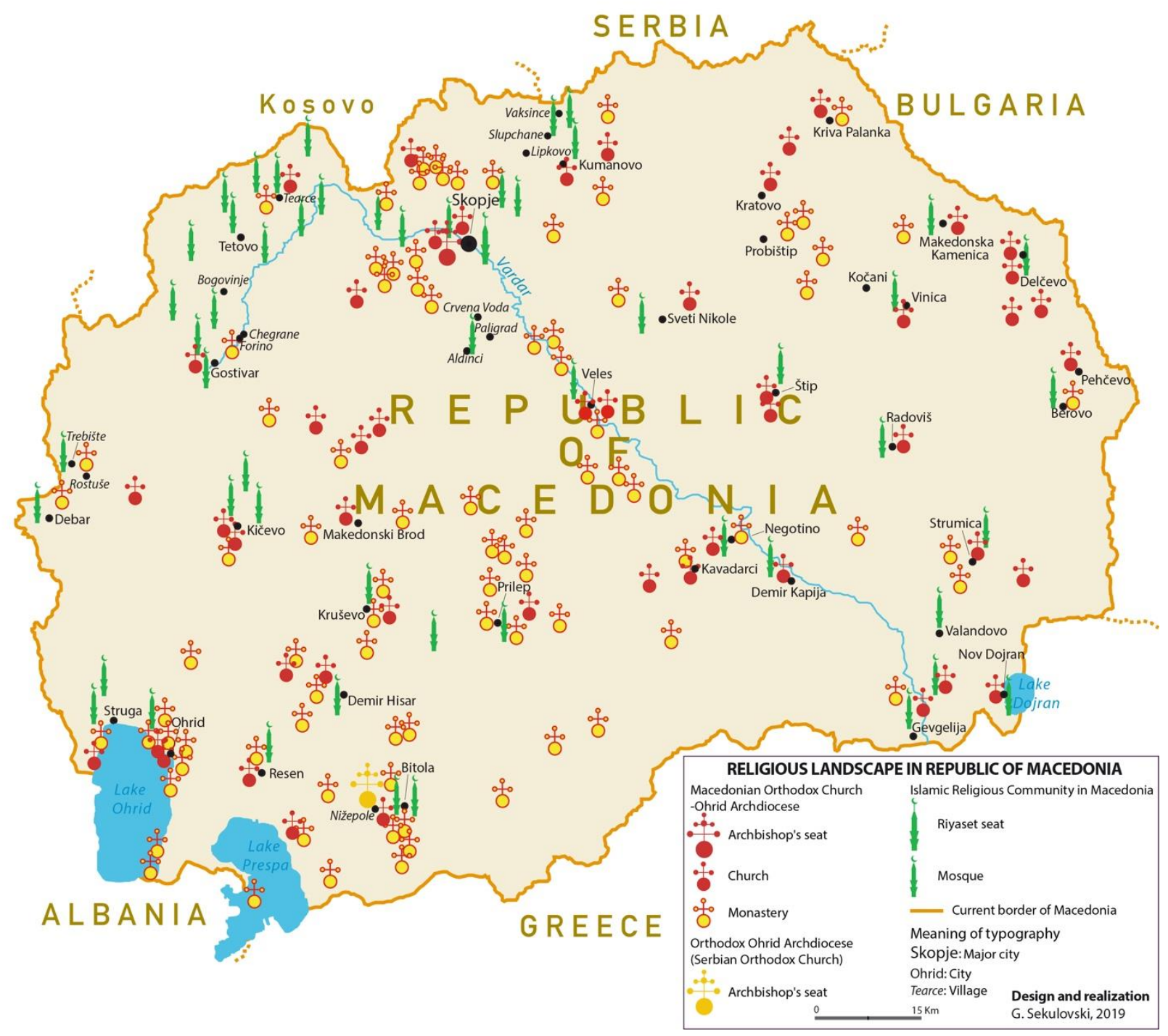

Figure 1: Map of religious landscape in Republic of Macedonia 


\section{References}

Brunet, R., R. Ferras and H. Thery. (1993). Les Mots de la Géographie, Dictionnaire Critique. Paris, La Documentation française.

Božinovski, V., and M. Nikolovski. (2016). Percepcijata na gragjanite za religijata $i$ nejzinata uloga vo multikonfesionalnite opstestva [Citizens' Perception of Religion and its Role in Multi-Confessional Societies]. Skopje, Fondacija Konrad Adenauer.

Božinovski, V., and M. Nikolovski. (2019). Makedonija kako multikonfesionalno opštestvo: percepcii za vlijanieto megju religijata $i$ državata [Macedonia as a Multi-Confessional Society: Perceptions of the Influence between Religion and the State]. Skopje, Fondacija Konrad Adenauer.

Cacanoska, R. (2016). "Religious Changes in Macedonian Society." Facta Universitatis Series: Philosophy, Sociology, Psychology and History vol. 15, n¹, p. 13-22.

Clayer, N. (2001). "Les dimensions islamiques de la crise en Macédoine et au Kosovo." In X. Bougarel and N. Clayer (eds.), Le Nouvel Islam Balkanique. Les Musulmans, Acteurs du Post-communisme (1990-2000), Paris, Maisonneuve et Larose, p. 177-240.

Clayer, N., and X. Bougarel. (2013). Les Musulmans de l'Europe du Sud-Est. Des Empires aux Etats Balkaniques. Paris, Karthala.

Debray, R. (2005). “A Bout de Souffle, l’Europe?,” Medium, vol. 4, p. 155-167.

Gardiner, M. Q. and S. Engler. (2010). “Charting the map metaphor in theories of religion," Religion vol. 40, n¹, p. 1-13.

Gjorgiev, D. (2011). “Ottoman Heritage in Macedonia: an Advantage or a Handicap?" Slavia Meridionalis, vol.11, p. 191-204 [in Macedonian].

Heller, A. (1996). “The Many Faces of Multiculturalism.” In R. Bauböck, A. Heller, and A. Zolberg (eds.), The Challenge of Diversity: Integration and Pluralism in Societies of Immigration, Avebury, Aldershot, p. 25-42.

Ilievski, P.-H. (1996). "Church-State Relations and Interconfessional Coexistence in Macedonia." Macedonian Review, vol. 26, n¹-2, p. 5-23.

Jahja, M. (2014). “Macedonia." In J. Nielsen, S. Akgönül, A. Alibašić and E. Racius (eds.), Yearbook of Muslims in Europe, vol. 6, Leiden, Brill, p. 398-408. 
Klekovski, S., A. Krzalovski, S. Sazdovska, and G. Jakovleska. (2008). Trust in the Civil Society. Skopje, Macedonian Center for International Cooperation.

Meer, N., T. Modood, and R. Zapata-Barrero. (2016). Interculturalism and Multiculturalism: Debating the Dividing Lines. Edinburgh, Edinburgh University Press.

Meyendorff, J. (1964). “Byzantine Views of Islam,” Dumbarton Oaks Papers vol. 18, p. 113-32.

Paasi, A. (2003). "Region and place: regional identity in question." Progress in Human Geography vol. 27, p. 475-485.

Papandreou, D. (1998). "La 9ème Consultation entre Chrétiens et Musulmans (Amman, 1-12 novembre 1998)." Episkepsis vol. 29, n563, p. 10-24.

Pavlovska, J., N. Nikiforovik, and O. Kocevski. (2011). Karta na verski objekti vo Republika Makedonija [Map of Religious Buildings in Republic of Macedonia]. Skopje, Komisija za odnosi so verskite zaednici i religiozni grupi.

Popović, A. (2009). L'Islam Balkanique. Les Musulmans du Sud-Est Européen dans la Période Post-Ottomane. Istanbul, Les Éditions ISIS.

Ramet, S. P. (2014). Religion and Politics in Post-Socialist Central and Southeastern Europe. Challenges since 1989. Houndmills, Palgrave Macmillan.

Sassen, S. (1996). "Analytic borderlands: race, gender and representation in the new city." In A. D. King (ed.), Re-presenting the city: ethnicity, capital, and culture in the 21st-century metropolis, New York, New York University Press, p. 183-202.

Sekulovski, G. (2014). “Qu'est-ce qu'Être Macédonien? Nation, Territoire et Orthodoxie en République de Macédoine," Géocarrefour vol. 89, n³, p. 193203.

Sekulovski, G. (2019). L'Échiquier Macédonien: Religion, Politique, Territoire. Paris, Éditions du Cerf.

Sharp, A. (2012). Orthodox Christians and Islam in the Postmodern Age. Leiden, Brill.

State Statistical Office. (2002). Census of Population, Households and Dwellings in the Republic of Macedonia. Final Data: Book X - Total Population According to the Ethnic Affiliation, Mother Tongue and Religion. Skopje, The State Statistical Office. 
Talbi, M., and O. Clément. (1989). Un Respect Têtu. Paris, Nouvelle Cité.

Tegovska, M., and I. Petkukeska. (2011). Megjureligiski dijalog vo Republika Makeodnija. Ternesko istrazuvanje za stavovite $i$ percepciite na gragjanite [Interreligious dialogue in Republic of Macedonia. Field research on Attitudes and Perceptions of Citizens]. Skopje, Institut za demokratija Societas Civilis.

Vermeulen, H., and Slijper B. (2002). "Multiculturalism and culturalism. A social scientific of the political philosophy of multiculturalism." In Nationalism, Regional Multiculturalism and Democracy, edited by A. Devic, Bonn: Zentrum für Europäische Integrationsforschung, 7-41.

Veschambre, V. (2004). “Appropriation et Marquage Symbolique de l'Espace: Quelques Éléments de Réflexion," ESO Travaux et Documents 21: 73-77. 